\title{
Development of Fraud Prevention (FP) Model Using the Theory of Planned Behavior
}

\author{
Razif Rosli \\ PhD Student/Graduate Research Assistant, Accounting Research Institute (ARI) \\ Universiti Teknologi MARA, 40450 Shah Alam, Selangor, Malaysia \\ E-mail: razifrosli@yahoo.com \\ Intan Salwani Mohamed (Corresponding author) \\ Research Fellow, Accounting Research Institute (ARI) \\ Universiti Teknologi MARA, 40450, Shah Alam, Selangor, Malaysia \\ Tel: 603-5544-4912; 603-5544-4992Ｅ-mail: intan838@uitm.edu.my
}

Nafsiah Mohamed

Professor, Accounting Research Institute (ARI)

Universiti Teknologi MARA, 40450, Shah Alam, Selangor, Malaysia

Tel: 603-5544-4985. E-mail: nafsiah793@salam.uitm.edu.my

\section{Rohana Othman}

Professor, Department of Accounting and Information Systems

University of Hail, Kingdom of Saudi Arabia

E-mail: rohana799@gmail.com

\author{
Nabilah Rozzani \\ Senior Lecturer, Faculty of Business Management and Professional Studies \\ Management and Science University, Shah Alam, Malaysia \\ E-mail: nabilah_rozzani@msu.edu.my
}


Received: July 7, 2020 Accepted: September 13, 2020 Published: September 25, 2020

doi:10.5296/ber.v10i3.17313

URL: https://doi.org/10.5296/ber.v10i3.17313

\begin{abstract}
Fraud is a global issue overwhelming all aspects of human economic and business activities as it poses potential threat of financial losses. Many detection and prevention mechanisms, such as internal control systems, operational audits, codes of conduct and forensic accounting have been applied in organizations aiming to effectively mitigate internal fraud activities. However, fraud is still occurring. This study is therefore aimed to develop a multidimensional theoretical model which explains factors (categorized under attitude, subjective norms and perceived behavioral controls) that influence Levers of Controls (LOC); how level of LOC could influence fraud prevention framework as well as whether LOC could mediate the relationship between planned behavioral variables and effective fraud prevention framework. Concerning more on the adoption and post-adoption stages regarding drivers of LOC, this study constructs a model in attempt to close the knowledge gaps found in prior studies. From literature review, theories relating with fraud prevention and behavioral controls were examined to identify knowledge gaps within previous measurements of effective fraud prevention framework. A multidimensional Fraud Prevention (FP) model is then developed by innovating the Theory of Planned Behavior (TPB).
\end{abstract}

Keywords: Fraud, Fraud prevention, Fraud prevention model, Theory of planned behavior

\title{
1. Introduction
}

Nowadays, everyone is concerned with fraud due to the massive losses driven by scandals discovered from corporate financial accounting (e.g., Tyco, WorldCom, and Enron), which had wiped out billions of dollars. From a study by Pricewaterhouse Coopers (2018), 49 per cent of respondents for the Global Economic Crime and Fraud Survey mentioned that their companies had became victims of fraud or economic crime. This trend showed an increment of 36 per cent in 2016, 37 per cent in 2014, 34 per cent in 2011, and 30 per cent in 2009. Results from this survey also showed that the rate of economic crime has increased across all territories, where Africa increased at 62 per cent in 2018 as compared to 57 per cent in 2016, the Asia Pacific increased at 46 per cent in 2018 as compared to only 30 per cent in 2016, Eastern Europe increased at 47 per cent in 2018 as compared to 33 per cent in 2016, Latin America increased at 53 per cent in 2018 as compared to 28 per cent in 2016, the Middle East increased at 35 per cent in 2018 as compared to 25 per cent in 2016, North America increased at 64 per cent in 2018 as compared to 37 per cent in 2016, and Western Europe increased at 45 per cent in 2018 compared to just 40 per cent in 2016.

Similarly, the Association of Certified Fraud Examiners (ACFE, 2018) concluded that Southeast Asia was also facing similar risk of fraud as other organisations across the globe. It was reported that there is an increase in percentage of crime in the region for the year 2018, where 46 per cent were victims of fraud or economic crime as compared to only 36 per cent 
in 2016 and 37 per cent in 2014. This reflects a slightly better position for the region as compared to the global average (49\%). This finding also represents a significant jump from prior years (26\% in 2016 and $28 \%$ in 2014). Evidence presented here supports the argument that many employers are secretly investigating and resolving internal fraud to minimize their risks and not exposing them to the public, minimizing adverse publicity exposure while at the same time fearing damage to public trust. This leads to the disclosure of Southeast Asia being reported as having an increase of crime rate at 46 per cent from being victims of fraud or economic crime in 2018. As a result, ACFE (2018) concluded that Southeast Asian crime may be caused by (1) 46 per cent experiencing fraud and economic crime, going up from 26 per cent in 2016, (2) 66 per cent of fraud and economic crime being committed by internal members of staff, (3) 12 per cent not performing any kind of economic crime-related risk assessment, (4) only 21 per cent implementing mechanisms to detect and report cybercrime, which is lower than the global average of 31 per cent, (5) 10 per cent leveraging on Artificial Intelligence or Advanced Analytics to counter fraud, where 77 per cent reported that they either don't know of any plans or have no plans to use Artificial Intelligence or Advanced Analytics, (6) 39 per cent experiencing business conduct or misconduct and 27 per cent experiencing procurement fraud, (7) $34 \%$ performing cyber-attack vulnerability risk assessment, where 39 per cent reported that they either do not know whether they have a Cyber Security program or they definitely do not have one, (8) 43 per cent of fraud being proactively detected through corporate controls and 32 per cent of fraud being reactively detected through corporate culture. The real statistics are painting a far darker picture.

In Malaysia, fraud is increasing and continues to be a problem (Aghlageh, Mohamed, \& Rahmat, 2016). Economic crime remains a fact of life for businesses in all industries. Pricewaterhouse Coopers (2018) claimed that organizations in Malaysia experience fraud and crime at a rate of 41 per cent, which is slightly lower than the rates in South East Asia (46\%) or globally (49\%). Pricewaterhouse Coopers (2018) also reported that 22 per cent of respondents who experienced fraud or economic crime in Malaysia in 2018 had reported financial losses from USD1 million and higher. This is slightly higher than the wider Southeast Asian region (15\%) and global view (18\%). Locally, this shows significant increase from 13 per cent in 2016. Clearly, the scale and impact of fraud have grown significantly in line with technological advancements.

In many organizations, fraud poses great obstacle to challenging business environment, giving impact to various areas of financial performance. It had been found that Malaysian corporations are facing similar risk of fraud as other organizations worldwide. This is with reference to previous studies which reported that many local companies such as Tat Sang Berhad, Transmile Group Berhad, and Megan Media Holdings Berhad were facing significant losses due to fraud (Mat Norwani, Mohamad, \& Tamby Chek, 2011). Besides that, a survey by KPMG (2004) found that 62 per cent of respondents felt that fraud poses big problem to Malaysian businesses, while another 83 per cent of respondents admitted having experienced fraud occurrences in their organizations. Occurrence of fraud is expected to lead towards an increment of economic crimes. It is expected to continually contribute towards the increasing rate of losses in business entities. This information can be used to develop fraud prevention 
frameworks to overcome fraud occurrences by giving suggestions to regulators as part of their effort to increase their investment in fraud control and reduce fraud occurrences (Tuan Mat et al., 2013).

The government sector is not excluded from experiencing impact of losses due to fraud (Ghazali, Rahim, Ali \& Abidin, 2014). Fraud occurrences in the public sector have always been and will continue to be a thorn inside any government in the world. According to the Malaysian Anti-Corruption Commission in 2011, it was reported that 35 per cent of arrested fraudsters were working in the public sector. These statistics present a 5 per cent increment of offenders as compared to the previous year, which was 2010.

A study by Mat Norwani, Mohamad, and Tamby Chek, (2011) indicated that few organizations have been suspected to commit public sector fraud and had caused big losses, such as the cases of Port Klang Free Zone (PKFZ), Perwaja Steel Sdn. Bhd. and Malaysia Airline Systems (MAS). Because of fraud, citizens may lose their trust in their government's leadership and capability to manage the country. This was highly concerned as the public as citizens had paid various taxes, such as personal taxes, in exchange to get the best services from government-related agencies (Zigenfuss, 1996). Pricewaterhouse Coopers (2011) mentioned that many organizations experienced collateral damage from significant impacts placed on employee morale, business relation, reputation as well as its public relations with revelations of fraud occurrences in the organizations.

\section{Problem Statement}

The rising numbers of cases involving financial statement fraud have received considerable attention following the collapse of several prominent firms in Malaysia (Malaysian Institute of Accountants, 2012). According to PWC report, in the two years since 2018 report, it have seen an increasing focus by Malaysian organizations in dealing with fraud and corruption. However, this year's report (2020) showed that the incidence of fraud and corruptions in Malaysia remains high with almost half of the survey respondents were victimized (PWC, 2020). The Malaysia Computer Emergency Response Team (MyCERT), under Cyber Security Malaysia (CSM) revealed that since 2008, cyber fraud made the highest number of incidents reported every year as compared to other cybercrimes, indicating that the level of awareness of this issue among internet users in the country is still low (Bernama, 2019). A total of 3,127 cases of cyber fraud were reported to MyCERT between January and July this year. Cyber fraud cases also topped the list last year, with 5,123 incidents reported, aside from 1,805 intrusions and 1,700 reports of malicious codes. The issue of "misconduct" had increased public scrutiny, which led to a decrease of public confidence towards employees in the public sector (Ahmad Sarji \& Mahmud, 1993). Public scrutiny has prompted a need to have effective fraud prevention framework due to acts of asset misappropriation by employees in the public sector (Dickey \& Nikias, 2008). Independent Commission against Corruption (2002) had listed some examples of behavior that lead to dishonest actions from employees in Malaysian Local Authorities; such as sending children to school using council vehicles or utilizing other assets such as computers, printers and internet connection for their personal use. 
Recently, the Malaysian Anti-Corruption Commission (MACC, 2019) reported that the total number of perpetrators arrested during that year was 1101, where the public official is 525 and civilian 576. However, in 2018, MACC (2019) reported that the total arrest was 894, with 418 public officials and 476 civilians. It shows an increasing trend from 2018 to 2019. Further, KPMG (2008) disclosed that 56 per cent out of a population of serious misconducts occurring in the government and public sector came from Local Authorities. According to Ahmad Sarji (1991), this prevalence is observable from cases of widespread public disclosures in concerns of questionable, negative, and illegal acts of public officials. This situation can also be observed by the increasing number of complaints received by the Public Complaints Bureau. There are 4059 complaints in 2008 as compared to 2941 complaints in 2007, and until September 2009, there had been 9709 recorded complaints (Public Complaints Bureau, 2009).

Based on previous literature, fraud prevention frameworks have been introduced by various parties such as KPMG, Ernst \& Young and others. However, the proposed fraud prevention framework is still not solving fraud from happening. Klynveld Peat Marwick Goerdele (KPMG) Malaysia conducted their own fraud survey and perceived that the trends of fraud are likely to be an on-going phenomenon from 2002 until 2004. KPMG survey in 2002 mentioned that 33 per cent of the studied companies have experienced fraud, experiencing losses up to RM 1 million. Incidences of fraud had also increased in 2004 as compared to 2002, being reported by another study by KPMG survey in 2004. KPMG survey (2004) showed that 83 per cent of respondents admitted to have had experience on fraud occurrence in their organizations. KPMG survey in 2004 showed that there has been a 33 per cent increment of fraud occurring in organizations as compared to the survey in the previous year. The survey had also found that secret commissions or kickbacks; hit and kiting; and false invoices were the three most common types of fraud faced by businesses in Malaysia (KPMG, 2004). Moreover, based on the findings of the Royal Commission of Enquiry, mismanagement of assets by Malaysian Local Authorities was caused by the lack of funding to these authorities, which leads to monetary fraud.

Moreover, from the preliminary investigation, it was found that Malaysian Local Authorities did not have a standardized fraud prevention framework, indicating each of the Local Authorities would present their report differently. Lack of standardization may hinder effective report review and pose several issues such as missing of specific information, as well as misinterpretation of terms while making comparisons or variances. Moreover, Local Authorities, such as district local authorities, face difficulties in implementing fraud prevention mechanisms due to shortage of knowledgeable workforce, lack of capital to hire complete team of internal audit, unstandardized guidelines and others.

Problem arising from literature review is with regards to the need in considering determinants of effectiveness fraud prevention. As such, determinants are selected by considering employee behavior which are adaptable using the Theory of Planned Behavior. Employee behavior can be described as a natural behavior to make wise decision based on good consequences without harming others. Although there are various factors in triggering dysfunctional acts in performance measurement and control system, there are limited studies 
that have been linked to the ethical aspects (Adnan, Muhammad Jamil \& Mohd Nor, 2012). Generally, ethical aspects of dysfunctional acts may well be viewed as an ethical issue, as it involves a predicament with moral component and volitions from the part of the decision maker to estimate its consequences for others (Douglas \& Wier, 2000). Theory of Planned Behaviour includes organization culture, employee integrity, employee intrinsic motivation, idealism-ethical ideology, organizational commitment and organization efficacy. Therefore, an understanding of issues and possible positive impacts on the effectiveness of fraud prevention framework using Theory of Planned Behaviour variables in Malaysian Local Authorities are crucial. In particular, the current study assesses on whether the inclusion of planned behavior variables in a theoretical model would provide or not a greater insight into what influences the head of department of Local Authorities (in doing what) with regard to the effectiveness of fraud prevention framework.

\section{Literature Review}

\subsection{Fraud Definition}

Oxford English Dictionary (2019) uses the term fraud to refer to wrongful or criminal deception intended to result in financial or personal gain. Meanwhile, Merriam Webster Dictionary (2019) refers fraud as a trick which is a crafty procedure or practice meant to deceive or defraud. Secondly, it refers to a trick which is a quick or artful way of getting a result. According to a definition provided by Wells (2005), fraud is an offense that ranges from asset misappropriation such as false overtime, use of company property for personal gain, salaries and sick time abuses, corruption and fraudulent statements including pilferage and petty theft. On the other hand, the Association of Certified Fraud Examiners (ACFE, 2012) defined fraud as an occupational fraud as the work of someone for personal enrichment through the deliberate misuse or abuse of resources or assets from an organization. In particular, misappropriation of assets is also the most common type of occupational fraud (ACFE, 2008). Accordingly, Sadique, Roudaki, Clark, \& Alias (2010) specified that fraud indicates misstatements arising from fraudulent financial reporting and misappropriation of assets. Although there are various definitions to the term fraud, the current study employs the definition of fraud as any intentional false representation, including failure to declare information or abuse of position that is carried out to make a gain, cause loss or expose another to the risk of loss. Therefore, for the current study, the term of fraud refers to a wrongful or criminal deception intended to result in financial or personal gain.

\subsection{Fraud Prevention}

Oxford English Dictionary (2019) uses the term fraud to refer to a wrongful or criminal deception intended to result in financial or personal gain. Oxford English Dictionary (2019) construed the term prevention as the action of stopping something from happening or arising. In cases of deliberate acts of fraud, preventative controls is aimed to reduce opportunity and remove temptation from potential offenders. Prevention techniques include the introduction of policies, procedures, and controls, as well as activities such as training and fraud awareness to stop fraud from occurring. It is profitable to prevent losses, as fraud prevention activities can help ensure the stability and continued existence of a business. However, based 
on recent surveys, many organizations do not have formal approach on fraud prevention. Once a fraud has occurred, the likelihood of recovering stolen funds from the perpetrator or through insurance is often relatively low. According to a survey by KPMG (2007), only 16 per cent of organizations which experienced fraud were able to recover their losses. Others struggled to recover their stolen assets, but the process is often difficult and lengthy. At least half of the organizations were unable to recover any assets at all. As such, it is preferable have efforts to prevent losses from occurring in the first place. The adage 'prevention is better than cure' certainly applies to fraud. It is worth to bear in mind that although fraud prevention techniques are worth investing in, they will not be able to provide 100 per cent protection to the business. It is difficult, if not impossible, to remove all opportunities of fraud. Therefore, for the current study, the term fraud prevention is used to describe a situation of "activities or procedures that are intended to secure the organization and its processes against fraud".

\subsection{Fraud Prevention Framework}

Fraud prevention framework is a framework or guideline which provides systematic procedure for the prevention of fraud, reporting of any fraud that is detected or suspected, as well as fair dealing of matters pertaining to fraud (Rorwana, Tengeh, \& Musikavanhu, 2015). Fraud prevention framework is also known as fraud policy, and it is an effective tool for preventing fraud (Taylor, 2011; Singleton \& Singleton, 2010). Fraud prevention framework ensures and provides guideline (1) to ensure that management is aware of its responsibilities for prevention of fraud, (2) to establish procedures for preventing fraud and/or detecting fraud when it occurs, (3) to provide clear guidance to employees and others dealing with organizations to forbid them from being involved in any fraudulent activity, where actions are to be taken if there is any fraudulent activity, (4) to conduct investigations into fraudulent activities, and (5) to provide assurances that any and all suspected fraudulent activity will be fully investigated. Examples of fraud prevention frameworks can be referred to Hepburn Shire Council (2014) and Victorian Auditor General Report (2012). As such, for the current study, the term fraud prevention framework is referred to as a guideline in providing a systematic procedure for the prevention of fraud, reporting of any fraud that is detected or suspected, also on fair dealings of matters pertaining to fraud.

\subsection{Theory of Planned Behavior}

In 1967, the Theory of Reasoned Action was first introduced by Ajzen and Fishbein (1980). Theory of Reasoned Action acted as an attempt to understand the relationship between attitude and behavior. This theory explains the relationship between faith, belief, behavior, and attitude. Theory of Reasoned Action states that the most appropriate determinant for behavior is behavioral intention. Attitude towards performing the behavior and subjective norms is further related to the behavior of determinants' intentions. The attitude of behavior can be described as a person's beliefs about the outcome or properties to perform certain behaviors (i.e. behavioral beliefs), weighted with their evaluation results or attributes. Moreover, subjective norms can be defined as someone referring matters that are important to others, agreeing or disagreeing with performance behavior such as normative beliefs, being weighted by the motivation of others to achieve requirements of the referrer (Ajzen \& 
Fishbein, 1980; Montano \& Kasprzyk, 2002).

Based on Ajzen \& Madden (1986), the Theory of Planned Behavior becomes a beginning of Fishbein and Ajzen's Theory of Reasoned Action, which incorporates the concept of behavioral control. Many factors can interfere with the control of desired behavior. These are some internal factors related to an individual such as abilities, planning, skills, and knowledge. Meanwhile, external factors are opportunities, time, and dependence on others. "To ensure an accurate prediction of behavior, in which the individual has only limited control, we must evaluate not only faith but also get some estimation of the extent to which an individual can exercise control over the conduct in question" (Ajzen \& Madden, 1986, p.456). However, it is rather difficult to ensure that adequate measures of actual control have taken place by simply observing the individual's behavior. Hence, Ajzen \& Madden (1986, p. 457) argued that there is a possibility to measure perceived behavioral control. According to the Theory of Planned Behavior, greater perceived control over behavior may occur with more resources and opportunities being available for individuals, and fewer barriers or obstacles being faced as compared to what they have expected. Two rationales surround the relationship between perceived behavioral control and behavior. The first one is the intention of holding constant, where the likelihood that behavior is carried out to increase perceived behavioral control becomes greater. The second one is that perceived behavioral control must reflect the actual control in situations with little accuracy (Ajzen \& Madden, 1986).

Theory of Planned Behavior (Figure 1) describes three determinants which affect behavior. Attitude refers to the degree to which a person has positive or negative feelings towards the behavior of interest. It entails a consideration of the outcomes of performing the behavior. Subjective Norm refers to the belief about whether significant others think that he or she will perform the behavior. It relates to a person's perception of the social environment surrounding the behavior. Perceived Behavioral Control (PBC) refers to the individual's perception of an extent to which performance of the behavior becomes easy or difficult (Ajzen, 1991). It increases when individuals perceive that they have more resources and confidence (Ajzen, 1985; Hartwick \& Barki, 1994; Lee \& Kozar, 2005).

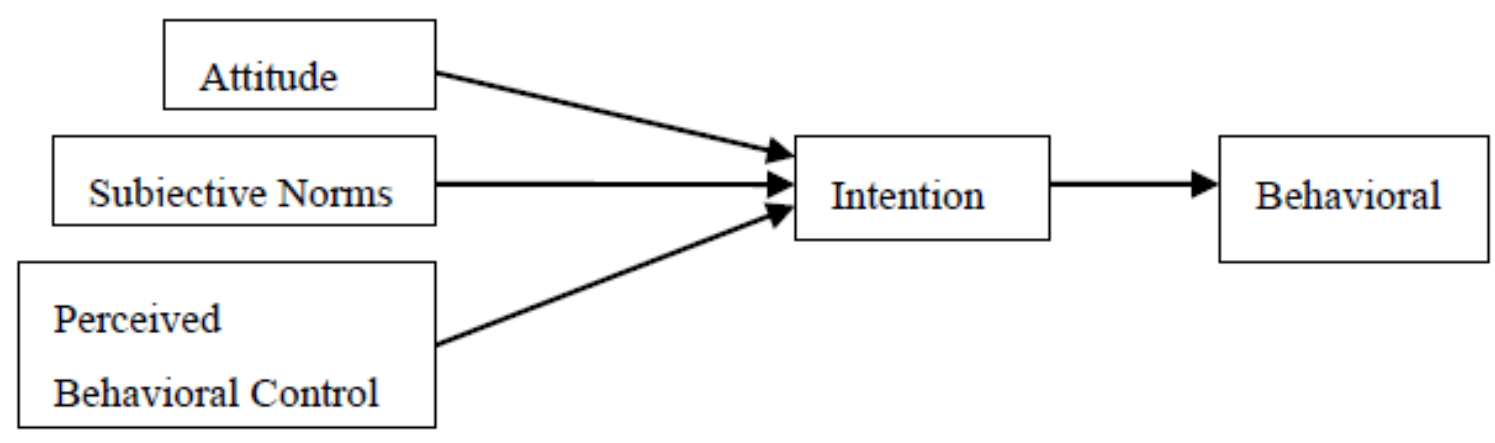

Figure 1. Theory of Planned Behaviour

Source: Ajzen 1991

Generally, the Theory of Planned Behavior is ideal for researches that apply individual level 
as a unit of analysis, such as the study of individual behaviors. However, some researchers contended that the Theory of Planned Behavior could also be applied in organizational level as a unit of analysis (e.g., Dodor \& Rana 2009; Koropp, Kellermanns, Grichnik, \& Stanley, 2014; Grandon \& Mykytyn 2004; Veronese \& Kensler 2013). In a study by Koropp, Kellermanns, Grichnik, \& Stanley (2014), the Theory of Planned Behavior was applied to investigate family firms' financial choices. The authors contended that business decisions of such firms are usually made by a single decision-maker who is typically the owner of the company. Dodor \& Rana (2009) applied the Theory of Planned Behavior in a context of organizational behavior. Theory of Planned Behavior was applied in this study by replacing individuals with the concept of representatives or actor as an action or behaviors of organizations Gavetti, Henrich, Daniel, \& Ocasio, (2012) also suggested that the behavior of managers while making decisions will govern the organization's behavior regardless of whether the decision is made personally or collectively. This ideology is also supported by a study by Cheng (2016), for which managers would act as representative to make decision, either as a single person or a group of people that determines whether the organization intends to form project partnering.

Although TPB is based on an assumption that behavioral intention is determined by three factors, namely; attitude, subjective norm, and $\mathrm{PBC}$, previous researches have mentioned that there are few domain-specific factors which were not included in this model (Armitage \& Conner, 2001; Donald, Cooper, \& Conchie, 2014). In recent times, increasing evidence had been noticed in the psychological literature to include additional constructs in TPB (Read, Brown, Thorsteinsson, Morgan, \& Price, 2013; Yazdanpanah \& Forouzani, 2015) in various domains to improve the predictive power of the framework. It was also suggested that the TPB framework can be deepened and broadened by adding new constructs or altering the path of the variables in it (Ajzen, 1991; Perugini \& Bagozzi, 2001). Based on supporting evidence from the literature, the current study attempts to include two additional constructs TPB within the case of green products such as environmental concern and environmental knowledge.

\section{Development of Fraud Prevention (FP) Model}

Developing the FP model, as shown in Figure 2, requires an exhaustive review of the literature to distinguish constructs. Considering critical components, literature related to planned behavior variable, levers of controls and viability extortion avoidance were further explored. A review of the literature suggests that FP model would fit together with the Theory of Planned Behavior (TPB).

TPB was created out of the rule of accumulation, to show which sets that a collection of particular behaviors over events would have way better predictive validity of attitudes and other characteristics than basically analyzing perceived Locus of Control (LOC) on it's own. TPB looks into addressing personal motivation components inside interesting settings to clarify the large execution of a particular behavior (Ajzen, 1991). In the current study, intentions behavior is more likely to be seen as the manager's deliberation in executing adequate FP. 
Intentions are expected to capture motivational components that impact behavior; they are signs of how difficult individuals are willing to take and how much of an exertion are they arranging to apply in performing the said conduct. As a common rule, the more grounded and deliberate a person to lock in a behavior, the more likely it would be executed (Taylor \& Todd, 1995). Hence, this becomes a role of LOC as mediator. It posits that LOC looks to measure management control towards their employee.

TPB (shown in Figure 1) hypothesized three conceptually independent determinants of intention (Ajzen, 1991). The primary free determinant of intention is attitude. Generally, attitudes allude an individual towards performing a given behavior. Attitude can be implied as a level of degree in which an individual has a positive or ominous assessment or evaluation of a particular behavior (Ajzen, 1991). Associated with attitudinal belief, the attitude of an individual would influence behavior which will lead to a specific result, weighted by an assessment of allure from that result (Taylor \& Todd, 1995). In the current study, organization culture, employee integrity and organizational commitment are grouped under attitude. Organization culture applies more to espoused values where espoused values mean to characterize an apparent acceptance of an organization. Organization culture consists of five components: (a) the value is a concept or belief (b) with respect to the desired behavior; (c) exceeds the value of the situation; (d) the assessment of behavioral guidelines and events; and (e) values that were well-arranged by the relative importance. This construct looks more on employee kindness. Organization culture focuses on the act of kindness which is meant to benefit others. It also means an act of doing good, forgiving, and helping a person in times of need without expecting anything in return. Organization culture is something which a person does over and above his duties. It fits the definition of attitude; for which attitude is equated with the attitudinal belief that performing behavior will lead to a particular outcome, weighted by an evaluation of desirability from that outcome. Definition of attitude also fits with employee integrity; where refers as individual "coherence" (Selznick, 1992), "personal commitment to principles" (Becker, 1998; Maccoby, 1988; Mayer, Davis, \& Schoorman, 1995), "honesty" (Yulk \& Van Fleet, 1992), and "private modal codes" (Barnard, 1968). Lastly, organizational commitment fits with the definition of attitude because the definition of organizational commitment is an attachment of an individual, emotionally, and functionally, to his/her place of work (Elizur \& Koslowsky, 2001, p.594). Mathieu \& Zajac (1990, p.171) described the organizational commitment as a bond or linking of an individual to an organization, which is related to his or her behavior. It can also be referred to as the degree at which a person has favorable or unfavorable evaluation or appraisal of the behavior in question.

The second independent determinant of intention is a social factor, or also known as subjective norm. Subjective norm refers to perceived social pressure to perform or not to perform one's behavior (Ajzen, 1991). Subjective norm is formed as an individual's normative belief concerning a particular referent, weighted by the motivation to comply with that referent (Taylor \& Todd, 1995). In the current study, employee intrinsic motivation is placed under subjective norms. Employee intrinsic motivation can be described as conducting an activity for its inherent satisfaction, rather than for some separable consequence (Ryan \& 


\section{Macrothink

Deci, 2000). Generally, an individual with employee intrinsic motivation does an action for the fun of it or to be involved with challenging activities. It is not driven by reward, external products, or pressures. This fits with the subjective norm's definition, which can be referred to as perceived social pressure to perform or not to perform one's behavior (Ajzen, 1991).

The third independent determinant of intention is the degree of seen behavioral control, which is referred to as perceived ease or trouble in performing one's behavior. It is expected to reflect past encounter as well as expected impediments and deterrents (Ajzen, 1991). As a common rule, the greater the attitude and subjective norm are associated with one's behavior; the more noteworthy the perceived behavioral control would be which indicates that an individual's intention to perform the conduct beneath thought will be more grounded. Perceived behavioral control is individual's control beliefs, weighted by perceived facilitation of control factor in either repressing or encouraging the behavior (Taylor \& Todd, 1995). Control convictions reflect seen trouble (or ease) with which the conduct may be performed (Ajzen, 1991). For the current study, organization efficacy and idealism-ethical ideology are assembled beneath seen behavioral control since the definition of organization efficacy, and idealism-ethical ideology fits beneath the definition of seen behavioral control. Organization efficacy is characterized as individuals' beliefs around their capability to prepare cognitive assets and courses of activities required to perform a particular assignment effectively inside a given setting (Bandura, 1982, 1997), while the definition of idealism refers to an inherent interest in the welfare of others and a degree in which intrinsic rightness of behavior determines which behavior should be engaged with (Forsyth, 1980).

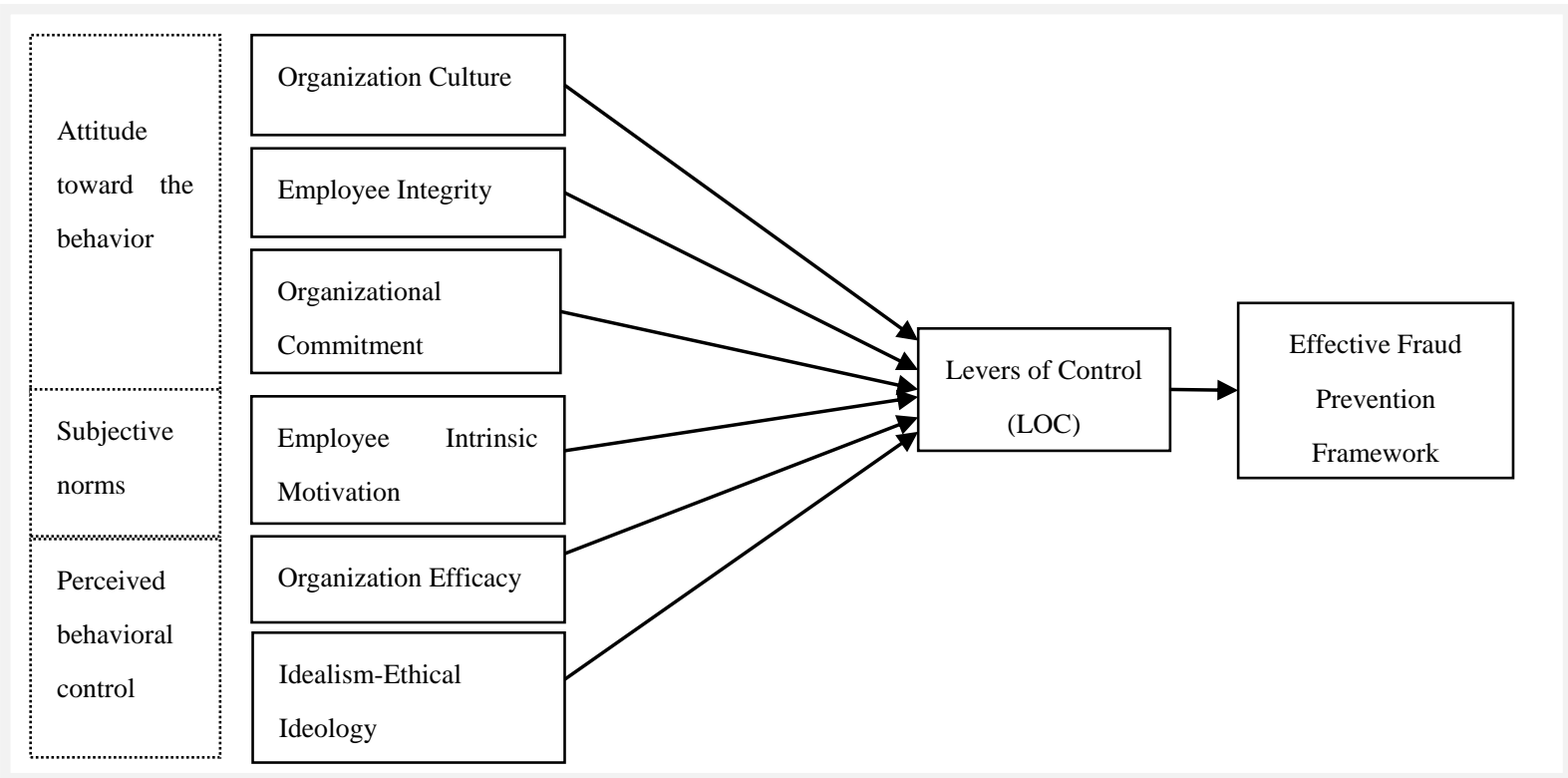

Figure 2. Proposed FP Model

\subsection{Organizational Culture}

Culture can be recognized at different levels, such as countries, religions, dialect bunches and 
families. Another critical level at which culture can be perceived is at the level of organizations. Concurring to Sackmann (1992: 141), the definition of culture in an organization involves a set utilization of a central concept, where the central concept utilized may incorporate belief systems (Harrison, 1972), a coherent set of beliefs (Sapienza, 1985) or essential presumptions (Wilkins \& Ouchi, 1983; Schein, 1985), vital understandings (Sathe, 1983), or the "collective programming of the human mind" (Hofstede, 1980). These concepts are utilized from a functionalist or an interpretative point of view, for which culture is something that an organization "has" as compared with something an organization "is" (Smircich, 1983; Sackmann, 1989). As analysts began to connect different sorts of culture to several factors such as execution (e.g. Wilkins \& Ouchi, 1983), culture has been identified as a component to realize administrative adequacy and control.

Amid this advancement, a more significant number of definitions of organizational culture have surfaced. Wilson (2001) observed four key components that show up in numerous of these definitions. First and foremost, organizational culture may be referred to as a shared phenomenon (e.g. Wilkins \& Ouchi, 1983). In this way, culture could be a learned item of group involvement. Where it is found, there is a determinable group with a critical history. Secondly, most authors accepted that there are at slightest two levels of culture: a visible and a more profound level, and a less visible level. The visible level comprises of behavior patterns, the psychical and social environment and the composed and talked dialect utilized by the group. The more profound, less visible level of culture relates to the group's values and its fundamental assumptions (Schein, 1984). The shared values comprise of the objectives and concerns that shape a group's sense of what "ought" to be. The third component of organizational culture concerns the way in which new individuals learn the culture. The handling of social socialization emerges informally from the existing representatives and formally through acceptance preparing programs. Lastly, corporate societies tend to alter gradually over time. Kotter and Heskett (1992) clarified that culture evolves as a result of the turnover of group individuals, the changes within the company's market environment and common changes in society. These four key components build up together to form the definition of organizational culture:

"Organizational culture is defined as the visible and less visible norms, values and behavior that is shared by a group of employees which shape the group's sense of what is acceptable and valid. These are generally slow to change, and group members learn them through both an informal and formal socialization process" (Wilson, 2001: 356).

As the definition of organizational culture is still being debated, the current study defined organizational culture as an act of kindness which is meant to benefit others. It can also refer to an act of doing good, while forgiving and helping a person in times of need without expecting anything in return. Organizational culture is something which a person does over and above his duties. The organizational cultures are measured using the leniency, service motives and consciousness of Allah and his prescribed priorities.

\subsection{Employee Integrity}

Employee integrity can be defined as individual "coherence" (Selznick, 1992), "personal 
commitment to principles" (Becker, 1998; Maccoby, 1988; Mayer et al., 1995) and "honesty" (Yulk \& Van Fleet, 1992), or "private modal codes" (Barnard, 1968, p. 263). However, in the field of ethics, employee integrity relates to the principle of self-imposed ethics, values, and moral autonomy (Solomon, 1993; DeGeorge, 1993; Kolb, 1988). For philosophical reasons, several scholars such as McFall, (1987), Williams (1973) and Taylor (1985) have considerably advanced their understanding of individual integrity by developing elaborated descriptions of the concept.

Following Calhoun (1995), employee integrity can be explained using three philosophies, which are: (1) integrated-self; (2) identity; and (3) clean-hands. From the perspective of integrated-self, integrity involves an integration of internal determinants of self's desires, evaluation, and commitment to the whole community. Within the scope of identity view, integrity means loyalty to projects and principles that represent the core of one's identity. Lastly, from the clean-hands view, integrity means maintaining transparency, morality, and honesty of one's actions. The first picture is an integrated self-picture where integrated self-picture of integrity outlines several conditions that require integrity. An individual will not just become a follower of the crowd, but he or she will stand for something and has his or her reason to take that stance. A person of integrity is willing to be accountable for the consequences following his beliefs (McFall, 1987), despite facing undesirable consequences. Therefore, there is an unconditional commitment towards something that determines what we think is important, which defines largely to private moral identity (second picture of personal integrity). In the third picture, employee integrity, clean-hands picture, integrity is a matter of support. Should the occasion arise, an individual will stand on the main principles that determine what the individual could have done through the agency and within the limits which he/she will not go beyond (here lies embedded and professional integrity). A person with integrity will not do unethical things, even if he can gain good results from the unethical things (Calhoun, 1995). This view captures the "action" part of the identity of the picture portrayed, for which individuals would stand for something that is not just a matter of personal identification with a set of values or principles, but also a commitment to overcome a defect of values (which means action).

With regard to the current study, integrity is focused at a personal level since the integrity has several of level such as organization integrity. There are several debates regarding the measurement of integrity. However, the current study measures employee integrity by honesty, coherence, and personal commitment to principles.

\subsection{Organizational Commitment}

Organizational commitment refers to an individual's feelings about the organization as a whole. It is the psychological bond that an employee has with an organization, and it is related to goal and value congruence, behavioral investments in the organization, and likelihood to stay with the organization (Mowday, Steers, \& Porter, 1982). Generally, Elizur \& Koslowsky (2001, p.594) defined organizational commitment as the attachment of an individual, emotionally and functionally, to his/her place of work. Organizational commitment can also be referred to as the relative strength of an individual's identification 
with involvement in a particular organization (Mowday, Steers, \& Porter, 1979, p.226). Moreover, organizational commitment can be described as totally normative pressures to act in a way which meets organizational goals and interest (Wiener, 1982, p.493). Next, O'Reilly and Chatman (1986, p.493) refers organizational commitment as the psychology attachment felt by a person for an organization. It reflects the degree to which an individual internalizes or adopts characteristics or perspectives of the organization. Furthermore, organizational commitment can also be defined as a psychological state that binds an individual to an organization which would reduce labor turnover (Allen \& Meyer 1980, p.14). Lastly, Mathieu and Zajac (1990, p.171) described organizational commitment as a bond or linking of an individual to an organization.

Allen and Meyer (1990) identified three general themes in attitudinal conceptualizations of organizational commitment, which are affective attachment, perceived costs, and obligation. The three-dimensional construct is defined as follows:

"The affective component of organizational commitment refers to the employee's emotional attachment to, identification with, and involvement in the organization. The continuance component refers to commitment based on the costs that the employee associates with leaving the organization. Finally, the normative component refers to the employee's feelings of obligation to remain with the origination." (Allen \& Meyer, 1990, p.1).

The three components of commitment are regarded as a psychological trait where employees experience at various degrees. Each component of the commitment gain experience in various strengths (Stallworth, 2003). This model is probably the most empirically tested model by researchers in the body of literature (Marchiori \& Henkin, 2004; Stallworth, 2003). For the first component, workers with higher affective commitment would stay in the organization because they personally wanted to. Secondly, a worker with high continuance commitment would stay because they needed to. Lastly, workers with high normative commitment would remain because they must remain. All components may depend on different backgrounds, for example, personal characteristics, work characteristics, duration of work, and others.

Since a mutual definition organizational commitment is still being debated, the current study refers organizational commitment as the attachment of an individual, emotionally, and functionally, to his/her place of work. The organizational commitment is measured using the attachment to the organization, emotionally to organization and functionality to the organization.

\subsection{Employee Intrinsic Motivation}

Employee motivation can be divided into two categories, which are employee intrinsic motivation and employee extrinsic motivation. However, the current study only focuses on employee intrinsic motivation. Employee intrinsic motivation can be described as conducting an activity for its inherent satisfaction, rather than for some separable consequence (Ryan \& Deci, 2000, pp. 56). Generally, employee intrinsic motivation is doing an action for the fun of 
it or being involved with challenging activities. In this case, external products or pressures do not drive a reward. Referring to White (1959), the phenomenon of employee intrinsic motivation was first recognized within experimental studies of animal behavior. White (1959) found that many organisms engage in exploratory, playful, and curiosity-driven behaviors without elements of reinforcement or reward. This spontaneous behavior, which does not look for any reason to play that role, bestows adaptive benefits on the organism. The positive experience is subsequently related to exercise and expansion of moral capacity of a person.

On the other hand, employee intrinsic motivation exists within individual's employee in the relationships between individuals and activities. People are intrinsically motivated to do some activities and not others. However, not everyone has intrinsic motivation to do one specific task. Some authors perceive employee intrinsic motivation as interesting tasks while others have defined it on the satisfaction that a person gets from intrinsically motivated involvement of tasks. The argument surfaced due to the existence of employee intrinsic motivation in the relationship between a person and his/her job. These different definitions derive from an argument that the concept of employee intrinsic motivation was proposed as a critical reaction to two behavioral theories that were dominant in empirical psychology from the 1940 s to the 1960 s.

Generally, motivation has two dimensions, which is intrinsic motivation and extrinsic motivation. With regard to the current study, the motivation is employee intrinsic motivation as the study looks into internal behavior factor. There are several debates regarding the measurement to use to measure the employee intrinsic motivation. In this study, the measurements of employee intrinsic motivation are self-esteem, self-satisfaction, and a sense of accomplishment.

\subsection{Organizational Efficacy}

The word efficacy has been initially presented by Gist (1987). Self-efficacy may be thought of as a superordinate judgment of execution capability which is initiated by the assimilation and integration of numerous execution determinants. Bohn (2010) has altered Gist's (1987) depiction of organizational efficacy as a superordinate judgment of organizational performance capability which is actuated by the assimilation and integration of numerous execution determinants including collaboration, vision and mission, and center and versatile capacity. Table 1 shows a summary of the evolution of organization efficacy. 
Table 1. Evolution of Organizational Efficacy Concept

\begin{tabular}{|l|l|}
\hline Bandura (1986) & $\begin{array}{l}\text { Perceived collective efficacy will impact what individuals } \\
\text { select to do as a gather, how much exertion they put into it } \\
\text { and their remaining control when gather endeavors fail to } \\
\text { create results. }\end{array}$ \\
\hline Shea \& Guzzo (1987) & $\begin{array}{l}\text { To perform viably, groups require at slightest a negligible } \\
\text { belief in their claim efficacy. }\end{array}$ \\
\hline Shamir (1990) & $\begin{array}{l}\text { Group individuals evaluate their collective efficacy to be } \\
\text { low, and individuals come to accept that applying exertion } \\
\text { toward a wanted objective makes little sense since the } \\
\text { chances of a fruitful group achievement are seen to be low. }\end{array}$ \\
\hline Zaccaro, Blair, Peterson, \& & $\begin{array}{l}\text { Collective efficacy as a sense of collective competence } \\
\text { shared among people when apportioning, planning, and } \\
\text { joining their assets in an effective concerted reaction to } \\
\text { particular situational requests. }\end{array}$ \\
\hline Bandura (1997) & $\begin{array}{l}\text { Perceived collective efficacy is characterized as a group's } \\
\text { shared belief in its conjoint capabilities to compose and } \\
\text { execute courses of activity required to deliver given levels } \\
\text { of achievements. }\end{array}$ \\
\hline $\begin{array}{l}\text { Gully, Incalcaterra, Joshi, \& } \\
\text { Beaubien (2002); Tasa, } \\
\text { Taggar, \& Seijts (2007) }\end{array}$ & $\begin{array}{l}\text { The collective efficacy of a gather has been appeared to } \\
\text { foresee the collective execution of that group. }\end{array}$ \\
\hline Bohn (2010) & $\begin{array}{l}\text { Organization efficacy is characterized as a generative } \\
\text { capacity inside an organization to manage successfully with } \\
\text { the requests, challenges, stressors, and openings it } \\
\text { experiences inside the trade environment. It exists as a } \\
\text { totaled judgment of the member's evaluation of their (a) } \\
\text { collective capacities, (b) mission or reason, and (c) sense of } \\
\text { strength in an organization. }\end{array}$ \\
\hline
\end{tabular}

Organizational efficacy is a term that is still being debated among the academician and alike. Specifically, there is a lack of using the organizational efficacy within the study of fraud prevention. As such, the current study employs organizational efficacy as one of the research variables, measured by the conscious of ability, conscious of emotional and locus of control.

\subsection{Idealism-Ethical Ideology}

Forsyth (1980) argued that moral judgment consisted of two orthogonal dimensions, which are idealism and relativism. Individuals with high idealism believe that "desirable consequences can, with the 'right' action, always can be obtained" (p. 176). They also feel that it was always possible to avoid harming others (Forsyth, 1992). Low scorers believe that regardless of the potential consequences to others, morally right actions are for those who want to maximize self-interest (Keller, 1997). In laymen's term, idealism can be described as 
the level of concern of an individual towards the welfare of others. According to Forsyth, Nye, \& Kelley, (1988), individuals with high idealism are also likely to support the ethics of caring. Idealism has also been found to correlate negatively towards social dominance orientation (Wilson, 2003) and Machiavellianism (Leary, Knight, \& Barnes 1986; McHoskey \& Hicks, 1999). Finally, McHoskey (1996) found positive relationship between right-wing authoritarianism and idealism. Specifically, McHoskey (1996) asserted that high idealists are less likely to engage in behavior that is contrary to the rules of an organization, such as defiance.

The second dimension of ethical ideology is relativism. Referring to Forsyth (1980), relativism can be described as the extent to which someone accepts or rejects universal moral rules. When there are some who are more preferred to choose moral in absolutes when deciding on which action is the "right" one, there are also others who take contextual information into account before making any conclusions. It means that people who are affected by contextual information are relativists. Relativists feel that the right decision depends on the complexity of the situation and also the people involved in it. Relativists also tend to be more dependent on circumstances and personal attitudes rather than ethical principles when judging the actions of others (Forsyth, 1992). On the other hand, low relativists tend to believe that the right thing is always the one that is in harmony with universal moral principles, norms, or law, depending on the context. However, McHoskey (1996) stressed that relativism is negatively associated with right-wing authoritarianism and tendency in adhering to organizations rules (Mudrack, 2005).

Generally, ethical ideology has two dimensions, which is relativism and idealism. In relation to the study, the ethical ideology is idealism because the study is looking at internal behavior factor. There are several debates regarding the measurement to use to measure the idealism-ethical ideology. In this study, the measurements of idealism-ethical ideology are inherent interest and intrinsic rightness of behavior.

\section{Discussion: The Potential Outcome of the Study}

Academic studies on the effectiveness of fraud detection and prevention are very common in the literature. Commercial and institutional reports on such issues are also easily retrieved. Studies on fraud issue had looked at multiple dimensions of fraud such as the causes, the practices and the effectiveness of the mechanisms used in mitigating the fraud. Concerning the mechanism, a different study produces different claims on the effectiveness of the mechanism adopted. Isa (2011) for example, claimed that "the literature on fraud consistently claimed that an effective internal control system (ICS) is the primary means of preventing, detecting, and correcting fraud and errors". In contrast, Efiong, Inyang and Joshua (2016) posited that "forensic accounting techniques appeared to be the most effective and are currently used in most developed countries of the world". Many other studies stated that seem inconsistent with others in the subject of the effectiveness of fraud prevention mechanisms.

Deviating from this track, that does not effectively contribute to the decrement of the fraud cases. The current study seeks to explore the psychological aspects that trigger the occurrence of fraud. In other words, this study attempts to explore the determinants or factors associated 
with and leads to the ineffectiveness of the fraud prevention framework. By this, the current study explores the root instead of the shoot of the cause as embarking at the root is deemed to be more beneficial rather than justifying the outcome. Understanding the internal behavioral factors that possibly lead to fraud physical or behavioral commitment would help in devising and formulating more comprehensive and effective prevention programs. While the existing fraud mechanisms concentrate more on post fraud conducts, the intentional determinants would help in tackling the pre fraud conduct that is internal to potential fraudster. The blend of both pre and post mechanisms complement each other in battling this universal organizational issue.

\section{Conclusions}

From the Malaysian context, the current research mainly aimed at driving the country's transition to high value-added and high-income economy with adequate preservation of financial sustainability. The target of the National Key Result Area (NKRA) to reduce crime, while at the same time fight corruption and fraud in Malaysia is a key focus of the Government Transformation Program (GTP). Aligned with this aim, issues regarding the effectiveness of the fraud prevention framework should be properly addressed. It is expected that by knowing the cause of the ineffectiveness of such programs, an appropriate solution may be formulated.

\section{Acknowledgement}

The research described in this paper is supported by the Institute of Research Management \& Innovation (IRMI), Universiti Teknologi MARA, Shah Alam, Selangor, Malaysia under the GIP grants 600-IRMI5/3/GIP(035/2019). It is also supported by Accounting Research Institute (ARI), Universiti Teknologi MARA.

\section{References}

ACFE. (2018). Report To The Nations 2018 Global Study On Occupational Fraud And Abuse, Asia-Pacific Edition: Association of Certified Fraud Examiners. [Online] Available: https://www.acfe.com/uploadedFiles/ACFE_Website/Content/rttn/2018/RTTN-Asia-PacificEdition.pdf

ACFE. (2018). Report To The Nations 2018 Global Study On Occupational Fraud And Abuse, Southern Asia Edition: Association of Certified Fraud Examiners. [Online] Available: https://www.acfe.com/uploadedFiles/ACFE_Website/Content/rttn/2018/RTTN-Southern-Asia -edition.pdf

Adnan, N. L., \& Muhammad, J. C., \& Mohd, N. N. A. (2013). Ethical Antecedents of Dysfunctional Behaviour in Performance Measurement and Control System. Canadian Center of Science and Education. Asian Social Science, 9(1).

https://doi.org/10.5539/ass.v9n1p29

Aghghaleh, S. F., Mohamed, Z. M., \& Rahmat, M. M. (2016). Detecting Financial Statement Frauds In Malaysia: Comparing The Abilities Of Beneish And Dechow Models. Asian Journal of Accounting and Governance, 7, 57-65. 
https://doi.org/10.17576/AJAG-2016-07-05

Ajzen, I. (1985). From intentions to actions: A theory of planned behavior. In J. Kuhl \& J. Beckman (Eds.), Action-control: From cognition to behavior (pp. 11-39). Heidelberg: Springer. https://doi.org/10.1007/978-3-642-69746-3_2

Ajzen, I. (1991). The theory of planned behavior. Organizational Behavior Human Decision Process, 50(2), 179-21. https://doi.org/10.1016/0749-5978(91)90020-T

Ajzen, I., \& Fishbein, M. (1980). Understanding attitudes and predicting social behavior. Englewood Cliffs, NJ: PrenticeóHall.

Ajzen, I., \& Madden, T. J. (1986). Prediction of goal-directed behaviour: Attitudes, intentions, and perceived behavioural control. Journal of Experimental Social Psychology, 22(5), 453-474. https://doi.org/10.1016/0022-1031(86)90045-4

Allen, N. J., \& Meyer, J. P. (1990). The measurement and antecedents of affective, continuance and normative commitment to the organization. Journal of Occupational Psychology, 63(1), 1-18. https://doi.org/10.1111/j.2044-8325.1990.tb00506.x

Armitage, C. J., \& Conner, M. (2001). Efficacy of the theory of planned behavior: A meta analytic review. British Journal of Social Psychology, 40, 471-499.

https://doi.org/10.1348/014466601164939

Association of Certified Fraud Examiners (2008). Report to the nations on occupational fraud and abuse. [Online] Available:

https://www.acfe.com/uploadedFiles/ACFE_Website/Content/documents/2008-rttn.pdf

Association of Certified Fraud Examiners (2012). Report to the nations on occupational fraud and abuse. [Online] Available:

https://www.acfe.com/uploadedFiles/ACFE_Website/Content/rttn/2012-report-to-nations.pdf

Bandura, A. (1982). Self-efficacy mechanism in human agency. American Psychologist, 37, 122-147. https://doi.org/10.1037/0003-066X.37.2.122

Bandura, A. (1986). Social foundations of thought and action: A social cognitive theory. Englewood Cliffs, NJ: Prentice- Hall, Inc.

Bandura, A. (1997). Self-efficacy: The exercise of control. New York: W. H. Freeman.

Barnard, C. I. (1968). The Functions of the Executive. Harvard University Press, Cambridge, MA, First edition in 1938.

Becker, T. E. (1998). Integrity in organizations: beyond honesty and conscientiousness. The Academy of Management Review, 23(1), 154-16. https://doi.org/10.2307/259104

Bernama (2019). Cyber scams top the list every year. [Online] Available:

https://www.nst.com.my/news/nation/2019/08/512452/cyber-scams-top-list-every-year

Bohn, J. (2010). Development and exploratory validation of an organizational efficacy scale. Human Resource Development Quarterly, 21, 227-251. https://doi.org/10.1002/hrdq.20048 


\section{Ml Macrothink}

Business and Economic Research ISSN 2162-4860 2020, Vol. 10, No. 3

Calhoun, C. (1995). Standing for something. The Journal of Philosophy, 92(5), 235-60. https://doi.org/10.2307/2940917

Cheng, E. W. L. (2016). Intentions to Form Project Partnering in Hong Kong: Application of the Theory of Planned Behavior. Journal of Construction Engineering and Management, 142, 04016075. https://doi.org/10.1061/(ASCE)CO.1943-7862.0001200

DeGeorge, R. T. (1993). Competing with Integrity in International Business. Oxford University Press, New York, NY.

Dodor, J. B. K., \& Rana, D. S. (2009). Investigating business schools' intentions about offering e-Commerce education using an extended Theory of Planned Behavior. Decision Sciences Journal of Innovative Education, 7(1), 195-220.

https://doi.org/10.1111/j.1540-4609.2008.00213.x

Donald, I. J., Cooper, S. R., \& Conchie, S. M. (2014). An extended theory of planned behavior model of the psychological factors affecting commuters' transport mode use. $J$. Environ. Psychol., 40, 39-48. https://doi.org/10.1016/j.jenvp.2014.03.003

Douglas, P. C., \& Wier, B. (2000). Integrating Ethical Dimensions into a Model of Budgetary Slack Creation. Journal of Business Ethics, 28, 267-277.

https://doi.org/10.1023/A:1006241902011

Efiong, E. J., Inyang, I. O., \& Joshua, U. (2016). Effectiveness of the Mechanisms of Fraud Prevention and Detection in Nigeria. Advances in Social Sciences Research Journal, 3(3), 206-217. https://doi.org/10.14738/assrj.33.1894

Elizur, D., \& Koslowsky, M. (2001). Values and organizational commitment. International Journal of Manpower, 22(7), 593-9. https://doi.org/10.1108/01437720110408967

Fishbein, M. (1967). Readings in attitude theory and measurement. New York, NY: Wiley.

Forsyth, D. R. (1980). A Taxonomy of Ethical Ideologies. Journal of Personality and Social Psychology, 39(1), 175-184. https://doi.org/10.1037/0022-3514.39.1.175

Forsyth, D. R. (1992). Judging the Morality of Business Practices: The Influence of Personal Moral Philosophies. Journal of Business Ethics, 11(5-6), 461-470.

https://doi.org/10.1007/BF00870557

Forsyth, D. R., Nye, J. L., \& Kelley, K. (1988). Idealism, Relativism, and the Ethic of Caring. Journal of Psychology: Interdisciplinary and Applied, 122(3), 243-248.

https://doi.org/10.1080/00223980.1988.9915511

Gavetti, G., Henrich, R. G., Daniel, A. L., \& Ocasio, W., (2012). The Behavioral Theory of the Firm: Assessment and Prospects. Academy of Management Annals, 6, 1-40.

https://doi.org/10.1080/19416520.2012.656841

Ghazali, M. Z., Rahim, M. S., Ali, A., \& Abidin, S. (2014). A preliminary study on fraud prevention and detection at the state and local government entities in Malaysia. Procedia Social and Behavioral Sciences, 164, 437-444. https://doi.org/10.1016/j.sbspro.2014.11.100 


\section{Macrothink}

Business and Economic Research ISSN 2162-4860 2020, Vol. 10, No. 3

Gist, M. E. (1987). Self efficacy: Implications for organizational behavior and human resource management. Academy of Management Review, 12, 72-485.

https://doi.org/10.5465/amr.1987.4306562

Grandon, E. E., \& Mykytyn, Jr. P. P. (2004). Theory-based instrumentation to measure the intention to use electronic commerce in small and medium sized businesses. Journal of Computer Information Systems, 44(3), 44-57.

Gully, S. M., Incalcaterra, K. A., \& Beaubien, J. M. (2002). A Meta-Analysis of Team Efficacy, Potency, and Performance: Interdependence and Level of Analysis as Moderators of Observed Relationships. Journal of Applied Psychology, 87(5), 819-832.

http://doi.org/10.1037//0021-9010.87.5.819

Harrison, R. (1972). Understanding your Organisation's Character. Harvard Business Review, 50 .

Hartwick, J., \& Barki, H. (1994). Measuring User Participation, User Involvement, and User Attitude. MIS Quarterly, 18, 59-82. https://doi.org/10.2307/249610

Hepburn Shire Council. (2014). Fraud prevention policy. [Online] Available:

https://www.hepburn.vic.gov.au/hepburn/wp-content/uploads/2015/04/Policy-45C-Fraud-Pre vention-Policy-19-08-2014.pdf

Hofstede, G. (1980). Culture's consequences: international differences in work-related values. Sage: Beverly Hills, CA.

Hofstede, G. (1997). Culture and Organisations: Software of the Mind: Intercultural Cooperation and its importance for Survival. McGraw-Hill.

Institute of Internal Auditors (IIA). (2013). International professional practices framework. United States of America: Institute of Internal Auditors.

Isa, T. (2011). Impacts and Losses Caused by the Fraudulent and Manipulated Financial Information on Economic Decisions. Review of International Comparative Management, 12(5), 929-939.

Keller, C. E. (1997). An Experimental Investigation of How Ethical Orientations, Tax Rates, Penalty Rates, and Audit Rates Affect Tax Compliance Decisions. Unpublished Doctoral Dissertation, University of Tennessee, Knoxville.

Kolb, D. A. (1988). Integrity, advanced professional development and learning. Philosophy, pp. 68-88.

Koropp, C., Kellermanns, F. W., Grichnik, D., \& Stanley, L. (2014). Financial decision making in family firms: An adaptation of the theory of planned behavior. Family Business Review. Advance online publication. https://doi.org/10.1177/0894486514522483

Kotter, J. P., \& Heskett, J. L. (1992). Corporate Culture and Performance. Free Press, New York, NY. 
KPMG (2004). KPMG Forensic Fraud Survey 2003 [Brochure]. KPMG LLP. [Online] Available: www.kpmg.com/aci/docs/fraud-survey-2004.pdf

Leary, M. R., Knight, P. D., \& Barnes, B. D. (1986). Ethical Ideologies of the Machiavellian. Personality and Social Psychology Bulletin, 12(1), 75-80.

Maccoby, M. (1988). Integrity: a fictional dialogue. In Srivastva et al. (Eds.), Executive Integrity: The Search for High Human Values in Organizational Life. Jossey-Bass.

Malaysian Anti-Corruption Commission. (MACC, 2019). Arrest Statistic. [Online] Available: https://www.sprm.gov.my/index.php/en/enforcement/statistics-on-arrests

Malaysian Institute of Accountants. (2012). Strategic direction. [Online] Available: http://www.mia.org.my/new/about_strategicdirection.asp

Marchiori, D. M., \& Henkin, A. B. (2004). Organizational commitment of a health profession faculty: dimensions, correlated and conditions. Medical Teacher, 26(4), 353-8. https://doi.org/10.1080/01421590410001683221

Mat, N. N., Mohamad, Z. Z., \& Tamby, C. I. (2011). Corporate Governance Failure and Its Impact on Financial Reporting Within Selected Companies. International Journal of Business and Social Science, 2(21).

Mathieu, J. E., \& Zajac, D. M. (1990). A review and meta-analysis of the antecedents, correlates and consequences of organizational commitment. Psychological Bulletin, 108(2), 171-194. https://doi.org/10.1037/0033-2909.108.2.171

Mayer, R. C., Davis, J. H., \& Schoorman, F. D. (1995). An interactive model of organizational trust. Academy of Management Review, 20, 709-34.

https://doi.org/10.5465/amr.1995.9508080335

McFall, L. (1987). Integrity. Ethics, 98(1), 5-20. https://doi.org/10.1086/292912

McHoskey, J. W., \& Hicks, B. (1999). Machiavellianism, Adjustment, and Ethics. Psychological Reports, 85, 138-142. https://doi.org/10.2466/pr0.1999.85.1.138

McHoskey, J. W. (1996). Authoritarianism and Ethical Ideology. Journal of Social Psychology, 136(6), 709-717. https://doi.org/10.1080/00224545.1996.9712247

Merriam Webster. (2019). Is access on 4th October 2019. [Online] Available: https://www.merriam-webster.com/dictionary/fraud

Montano, D. E., \& Kasprzyk, D. (2002). The theory of reasoned action and the theory of planned behavior. In K. Glanz, B. K. Rimer \& F. M. Lewis, (Eds.), Health behavior and health education: Theory, research, and practice (pp. 67-98.). Wiley \& Sons, Inc; San Francisco.

Mowday, R., Steers, R., \& Porter, L. (1979). The measurement of organizational commitment. Journal of Vocational Behavior, 14, 224-247. https://doi.org/10.1016/0001-8791(79)90072-1

Mowday, R. T., Porter, L. W., \& Stress, R. M. (1982). Employee organisation linkages: The 
psychology of commitment, absenteeism and turnover. New York: Academic Press.

Mudrack, P. E. (2005). Utilizing Moral Reasoning: The Role of Deference to Authority. Proceedings of the Administrative Sciences Association of Canada, Toronto, Ontario, Canada.

O'Reilly, III, C., \& Chatman, J. (1986). Organizational Commitment and Psychological Attachment: The Effects of Compliance, Identification and Internalization on Prosocial Behavior. Journal of Applied Psychology, 71(3), 492-499.

https://doi.org/10.1037/0021-9010.71.3.492

Oxford English Dictionary. (2019). Fraud. [Online] Available:

https://en.oxforddictionaries.com/definition/fraud

Perugini, M., \& Bagozzi, R. P. (2001). The role of desires and anticipated emotions in goal-directed behaviors: broadening and deepening the theory of planned behavior. Journal Social Psychology, 40, 79-98. https://doi.org/10.1348/014466601164704

PriceWaterhouseCooper (PWC) (2018). Pulling fraud out of the shadows, Global Economic Crime Survey 2018. [Online] Available:

https://www.pwc.com/gx/en/forensics/global-economic-crime-and-fraud-survey-2018.pdf

PriceWaterhouseCooper (PWC) (2018). PwC's Global Economic Crime and Fraud Survey 2018, Southeast Asia Report. [Online] Available:

https://www.pwc.com/my/en/assets/publications/2018/gecfs-sea-2018-v9.pdf

Public Complaints Bureau website. [Online] Available: Http://www.pcb.gov.my/

PWC. (2020). PwC Global Economic Crime and Fraud Survey 2020-Malaysia Report. Fraud and corruption, Malaysia has its say. [Online] Available:

https://www.pwc.com/my/en/assets/publications/2020/PwC-Global-Economic-Crime-and-Fra ud-Survey-2020-Malaysia-report.pdf

Read, D. L., Brown, R. F., Thorsteinsson, E. B., Morganm, M., \& Price, I. (2013). The theory of planned behaviour as a model for predicting public opposition to wind farm developments. Journal Environment Psychology, 36, 70-76. https://doi.org/10.1016/j.jenvp.2013.07.001

Rorwana, A., Tengeh, R., \& Musikavanhu, T. (2015). A fraud prevention policy: Its relevance and implication at a university of technology in South Africa. Journal of Governance and Regulation (online), 4, 212-221. https://doi.org/10.22495/jgr_v4_i3_c2_p3

Ryan, R. M., \& Deci, E. L. (2000). Self-determination theory and the facilitation of intrinsic motivation, social development, and well-being. American Psychologist, 55(1), 68-78. https://doi.org/10.1037/0003-066X.55.1.68

Sackmann, S. A. (1989). Kulturmanagement: Läßt sich Unternehmenskultur 'machen'? In K. Sandner (Ed.), Politische Prozesse in Unternehmen (pp 157-183). Springer, Berlin et al. https://doi.org/10.1007/978-3-642-97145-7_7

Sackmann, S. A. (1992). Culture and subcultures: An analysis of organizational knowledge. Administrative Science Quarterly, 37(1), 140-161. https://doi.org/10.2307/2393536 
Sadique, M. R. B., Roudaki, J., Clark, M. B., \& Alias, N. (2010). Corporate Fraud: An Analysis of Malaysian Securities Commission Enforcement Releases. World Academy.

Sapienza, A. M. (1985). Believing is seeing: How organizational culture influences the decisions top managers make. In R. Kilmann, M. Saxton, R. Serpa \& Associates (Eds.), Getting control of the corporate culture. San Francisco: Jossey-Bass.

Sathe, V. (1983). Implications of Company Culture: A Manager's Guide to Action. Organizational Dynamics Autumn, 5-23. https://doi.org/10.1016/0090-2616(83)90030-X

Schein, E. H. (1985). Organizational culture and leadership. San Francisco, CA: Jossey-Bass.

Schein, E. H. (2010). Organizational culture and leadership (4th edition). San Francisco, CA: Jossey Bass.

Selznick, P. (1992). The Moral Commonwealth: Social Theory and the Promise of Community. University of California Press, Berkeley, CA.

Shamir, B. (1990). Calculations, Values, and Identities: The Sources of Collective Work Motivation. Human Relations, 43(4), 313. http://doi.org/10.1177/001872679004300402

Shea, G. P., \& Guzzo, R. A. (1987). Group Effectiveness: What Really Matters?. Sloan Management Review, 28(3), 25. [Online] Available:

http://www.ub.uni-koeln.de/openurl?url_ver=Z39.88-2004\&rft_val_fmt=info:ofi/fmt:kev:mtx :journal\&genre=article\&sid=ProQ:ProQ:abiglobal\&atitle=Group+Effectiveness: + What + Real ly+Matters? \& title=Sl

Singleton, T. W., \& Singleton, A. J. (2010). Fraud auditing and forensic accounting. 4th ed. John Wiley \& Sons. Newrsey. https://doi.org/10.1002/9781118269183

Smircich, L (1983). Concept of Culture and Organisational Analysis, Administrative Science Quarterly, 28, 339-358. https://doi.org/10.2307/2392246

Solomon, R. C. (1993). Ethics and Excellence: Cooperation and Integrity in Business. Oxford University Press, New York, NY.

Stallworth, H. L. (2003). Mentoring, organizational commitment and intentions to leave public accounting. Managerial Auditing Journal, 18(5), 405-18.

https://doi.org/10.1108/02686900310476873

Taylor, G. (1985). Integrity, Pride, Shame and Guilt: Emotions of Self-assessment. Oxford, New York, NY.

Taylor, S., \& Todd, P. (1995). Understanding lnformation Technology Usage: A Test of Competing Models. Information Systems Research, 6(2), 144-176.

https://doi.org/10.1287/isre.6.2.144

Taylor, J. (2011). Forensic Accounting. Pearson Education. Harlow.

Tuan, M. T. Z., Syed, M. N. S. N. F., Mohd, F. F., Ismail, A. M., \& Smith, M. (2013). 
Assessing the fraud prevention Mechanisms in Malaysian Government agencies. Malaysian Accounting Review, 12(2).

Uttal, B. (1983). The corporate culture vultures. Fortune Magazine, 17.

Veronese, D., \& Kensler, L. (2013). School leaders, sustainability, and green school practices: An elicitation study using the Theory of Planned Behavior. [Online] Available:

http://www.susted.com/wordpress/content/2458_2013_02/

Victorian Auditor General Report (2012). Fraud Prevention Strategies in Local Government. [Online] Available:

https://www.parliament.vic.gov.au/file_uploads/20120606-Fraud-in-LG_5t9vvn3X.pdf

Wells, J. T. (2005). Principles of Fraud Examination. New Jersey: John Wiley.

White, R. (1959). Motivation reconsidered: The concept of competence. Psychological review, 66, 297-333. https://doi.org/10.1037/h0040934

Wiener, Y. (1982). Commitment in organization: A normative view. Academy of Management Review, 7, 418-428. https://doi.org/10.5465/amr.1982.4285349

Wilkins, A. L., \& Ouchi, W. G. (1983). Efficient cultures: Exploring the relationship between culture and organizational performance. Administrative Science Quarterly, 28, 468-481. https://doi.org/10.2307/2392253

Williams, B. (1973). Integrity. In J. J. C. Smart \& B. Williams (Eds.), Utilitarianism: For and Against. Cambridge University Press, Cambridge, MA.

Wilson, A. (2001). Understanding organisational culture and the implications for corporate marketing. European Journal of Marketing, 35, 353-367.

https://doi.org/10.1108/03090560110382066

Wilson, M. S. (2003). Social Dominance and Ethical Ideology: The End Justifies the Means. The Journal of Social Psychology, 143(5), 549-558.

https://doi.org/10.1080/00224540309598462

Yazdanpanah, M., \& Forouzani, M. (2015). Application of the Theory of Planned Behaviour to predict Iranian students' intention to purchase organic food. Journal of Cleaner Production, 107, 342-352. https://doi.org/10.1016/j.jclepro.2015.02.071

Yukl, G., \& Van Fleet, D. D. (1992). Theory and research on leadership in Organizations. In M. D. Dunnett \& L. M. Hough (Eds.), Handbook of Industrial and Organizational Psychology (pp. 147-197). Palo Alto, CA: Consulting Psychologist Press.

Zaccaro, S. J., Blair, V., Peterson, C., \& Zazanis, M. (1995). Collective efficacy. In Self-efficacy Adaptation and Adjustment Theory Research and Application, pp. 305-328. https://doi.org/10.1007/978-1-4419-6868-5_11

Ziegenfuss, D. E. (1996). State and Local Government Fraud Survey for 1995. Managerial Auditing Journal, 11(9), 50-55. https://doi.org/10.1108/02686909610150395 


\section{Copyright Disclaimer}

Copyright for this article is retained by the author(s), with first publication rights granted to the journal.

This is an open-access article distributed under the terms and conditions of the Creative Commons Attribution license (http://creativecommons.org/licenses/by/4.0/). 